\title{
Phenotypic Variability of White Lupine (Lupinus albus L.) Germplasm
}

\author{
Natalia GEORGIEVA ${ }^{1 *}$, Valentin KOSEV ${ }^{2}$ \\ ${ }^{1}$ Institute of Forage Crops, Department of Technology and Ecology of Forage Crops, Pleven, Bulgaria; imnatalia@abv.bg (*corresponding author) \\ ${ }^{2}$ Institute of Forage Crops, Department of Breeding of Forage Crops, Pleven, Bulgaria; valkosev@hotmail.com
}

\begin{abstract}
Collecting, exploring and using a suitable, genetically diverse source material with different ecological-geographical origin is a determining prerequisite for the breeding success. The present study was conducted during the 2014-2016 period at the Institute of Forage Crops (Pleven, Bulgaria) with 23 cultivars of white lupine originating Poland, Russia and Ukraine. It was found a significant genetic diversity among the studied cultivars, which was a good prerequisite for starting a breeding program within the crop. The most favorable combination of a high seed productivity and crude protein content had cultivars 'Tel Keram', 'Pflugs Ultra', 'WAT', 'Solnechnii' and 'Pink Mutant', whose plants were also characterized by a mass of 1,000 seeds between 15 and $21 \mathrm{~g}$. Genetically, the most distant from each other were 'Bezimenii 1' and 'Pflugs Ultra' compared to 'Termis Mestnii' and 'Solnechnii' as well as to 'Tel Keram'. These cultivars are suitable as genitors for the development of high-yielding white lupine cultivars. Studied traits of pod length, number of seeds in a pod and seeds per plant showed a high positive phenotypic and genotypic correlation with the seed productivity in white lupine. Regarding productivity, it can be rely upon the mass of 1,000 seeds, plant height and number of seeds per plant due to their high total effect on the seed weight per plant.
\end{abstract}

Keywords: correlation, diversity, genetic advance, heritability, lupine

Collecting, exploring and using a suitable, genetically diverse source material with different ecologicalgeographical origin was a determining prerequisite for the breeding success (Valcheva and Vulchev, 2008; Khaidizar $e t$ al., 2012). The main genetic and breeding problems were related to increasing productivity and improving grain quality, some morphological, biological and physiological

\section{Introduction}

The Lupinus genus consisted of more than 300 species, but only four of them have acquired importance as agricultural crops: L. albus, L. angustifolius, L. luteus and L. mutabilis (Yorgancilar et al., 2009). Lupinus albus L. ( $2 \mathrm{n}=$ 50 chromosomes) an annual or perennial legume belonging to legume family Fabaceae, is one of the oldest crops. It was a major food legume in the Old World and had a long history of cultivation in the countries of the Mediterranean basin.

White lupine has a wide range of distribution (Kurlovich, 2002; Wolko et al., 2011; El-Harty et al., 2016). It had the capacity to grow under environmental and edaphic conditions that are not tolerated by other crops. Large genetic diversity exists in morphological and agronomic traits in $L$. albus as a result of both natural and human selection (Jansen, 2006).

The conservation and preservation of the genetic resources of this species were of crucial importance for the breeding programs related to the improvement of the cultivar composition in the white lupine (Raza and Jornsgard, 2005; El-Sherif et al., 2014). traits and properties of culture (Caliskan et al., 2013). The solution of these problems was related to the necessity of applying complicated genetic and mathematical-statistical methods and conducting systematic researches and analysis of the main selective traits of the materials in the work collection (Ayan et al., 2012).

The knowledge of genetic diversity is a useful tool in gene-bank management and breeding experiments like tagging of germplasm, identification and/or elimination of duplicates in the gene stock and establishment of core collections (Aliu et al., 2016).

The purpose of this study was to assess the genetic diversity and biological potential of white lupine accessions regarding components of productivity.

\section{Materials and Methods}

\section{Biologicalmaterial}

The study was conducted during the 2014-2016 period at the Institute of Forage Crops (Pleven, Bulgaria). The 
398

working collection included 23 cultivars of white lupine (Lupinus albus L.) as follows: 'Solnechnii', 'Pflugs Ultra', 'Tel Keram', 'Bezimenii 1', 'Bezimenii 2', 'Dega', 'Manovitskii', 'Barde', 'Desnyanskii', 'Termis Mestnii', 'Pink Mutant', 'Horizont' (Russian cultivars); 'Astra', 'Ascar', 'Amiga', 'BGR 6305', 'Kijewskij Mutant', 'Hetman', 'Nahrquell', 'Shienfield Gard', 'Start', 'WAT' (Polish cultivars) and 'Garant' (an Ukrainian cultivar).

\section{Experimental sampling design and qualitative analysis}

The experiment was carried out in a field for organic production after a two-year conversion period. A randomized block method was used. The seeds were sown by hand, in the third decade of March with a sowing rate of 50 seeds per $\mathrm{m}^{2}$. The following traits and indicators were reported: plant height $(\mathrm{cm})$, height to first pod $(\mathrm{cm})$, number of pods per plant, number of seeds per plant, mass of 1,000 seeds $(\mathrm{g}$ ), seed weight per plant $(\mathrm{g})$, pod length $(\mathrm{cm})$, pod width $(\mathrm{cm})$, content of crude protein (CP, $\mathrm{g} \mathrm{kg}^{-1}$ dry matter) and crude fiber (CF, $\mathrm{g} \mathrm{kg}^{-1}$ dry matter). Broad sense heritability (Hbs) was calculated for all traits by using the formula proposed by Mahmud and Kramer (1951).

\section{Statistical procedures}

The level of genetic diversity was established using coefficients and parameters - genotypic coefficient of variation $(\mathrm{CVg})$ and phenotypic coefficient of variation (GVe) were estimated by the formula suggested by Burton (1952). The statistical methods were used to process the experimental data: factor analysis by the method of principal components (Vandev, 2003); hierarchical cluster analysis by the method of Ward (1963) - for the grouping of genotypes by similarity as a measure for the difference (the genetic distance), the Euclidean distance between them was used, having previously standardization of the data carried out. Genetic advance in absolute unit (GA) and genetic gain (GG), assuming selection of the superior $5 \%$ of the genotypes, were evaluated in accordance with the methods of Johnson $e t$ al. (1995), using the software GENES 2009.7.0 for Windows XP (Cruz, 2009). The dependencies between indicators were established by correlation analysis (Sharma and Choubey, 1985). Statistical analysis of the data was based on a dispersion analysis of the particular traits.

All experimental data were processed statistically using the computer software SPSS 13 and Excel for Windows XP.

\section{Results}

Genetic diversity of germplasm resulting from the enrichment of available genetic resources largely determined the scope of breeding activity in a particular crop. Preliminary assessment of the breeding accessions from the collection, analysis of genetic parameters and inheritance of basic traits and indicators was of primary importance in the breeding of new varieties with improved qualitative and quantitative composition (Ajmal et al., 2009; Bozokalfa et al., 2010; Esiyok et al., 2011).

In the recombinative plant breeding, there was a considerable interest regarding the information about the genetic proximity or distance of the genotypes used as parental forms in hybrid combinations. Transgressive degradations can be expected to a greater extent if genetically distanced accessions were crossed. Then it is expected to combine different genes from both parents in the offspring, determining the desired traits (Cowen and Frey, 1987).

In the conditions of the present experiment, 23 white lupine cultivars were studied in terms of biological and economically valuable qualities. According to the dispersion analysis presented (Table 1), statistically significant differences between the tested cultivars were found for the following traits: pods per plant, seeds in a pod, seeds per plant, seed weight per plant, mass of 1,000 seeds, content of crude protein and crude fiber. As a whole, in the collection of accessions, the differences in regard to plant height, pod width and length were statistically insignificant.

\section{Principal component analysis}

Based on the studied 10 traits, a factor analysis was performed using the main components' method in the collection of white lupine accessions. There were three eigen values greater than 1 , which determined the choice of three main components (Table 2). These major components explained about $81.63 \%$ of the total variation. The first component explained $48.65 \%$, the second one - $21.98 \%$, the third $-10.99 \%$ of the whole variation. The first component was primarily related to the traits of plant height, pods per plant, pod width and length, seeds per plant. The seeds in a pod and seed weight per plant participated in the formation of the second component, and the mass of 1,000 seeds - in the formation of the third component.

Fig. 1 presented the disposition of the cultivars according to their values regarding the first (PC1) and the second (PC2) component. Cultivars 'WAT', 'Start', 'Amiga', 'Garant', 'Manovitskii', 'Dega', 'Desnyanskii' and 'Hetman' had negative values for $\mathrm{PCl}$ and positive ones for PC2. The position that they occupied on the coordinate system was determined by the fact that the plants did not reach a great height, they formed a medium number of pods per plant and had a lower productivity.

The accessions 'Bezimenii 1', 'Bezimenii 2', 'Pflugs Ultra', 'Termis Mestnii' and 'Pink Mutant' had a positive value in terms of PC1 and a negative one for PC2. The location of these accessions was determined by that they succeeded to form higher plants, more pods per plant, and the seed weight per plant and the mass of 1,000 seeds were above the averages for the studied group. They were also characterized with a lower crude fiber content.

Table 1. Dispersion analysis (ANOVA) for the studied traits in white lupine cultivars

\begin{tabular}{cccccccccccc}
\hline $\begin{array}{c}\text { Source of } \\
\text { variation }\end{array}$ & DF & $\begin{array}{c}\text { Plant } \\
\text { height }\end{array}$ & $\begin{array}{c}\text { Pods per } \\
\text { plant }\end{array}$ & $\begin{array}{c}\text { Pod } \\
\text { width }\end{array}$ & $\begin{array}{c}\text { Pod } \\
\text { length }\end{array}$ & $\begin{array}{c}\text { Seeds per } \\
\text { pod }\end{array}$ & $\begin{array}{c}\text { Seeds per } \\
\text { plant }\end{array}$ & $\begin{array}{c}\text { Seed weight per Mass of 1,000 } \\
\text { plant }\end{array}$ & $\begin{array}{c}\text { Crude } \\
\text { seeds }\end{array}$ & $\begin{array}{c}\text { Crude } \\
\text { protein }\end{array}$ & fiber \\
\hline Blocks & 2 & $4,013.76$ & $1,191.24$ & 439.37 & $9,199.25$ & 447.98 & $3,121.73$ & 0.44 & 0.0427 & 0.002 & 0.13 \\
Treatments & 22 & $516.45 \mathrm{~ns}$ & $106.93^{*}$ & $25.15 \mathrm{~ns}$ & $588.59 \mathrm{~ns}$ & $48.60^{* *}$ & $3,956.02^{* *}$ & $0.83^{* *}$ & $0.06^{* *}$ & $18.24^{* *}$ & $11.04^{* *}$ \\
Residuo & 44 & 410.77 & 53.45 & 25.25 & 405.57 & 18.08 & $1,512.15$ & 0.20 & 0.0211 & 0.26 & 0.50 \\
\hline${ }^{* *},{ }^{*}$ significance at $\mathrm{p}<0.01$ and $\mathrm{p}<0.05$ probability levels; ns - not significantly different & & & &
\end{tabular}

, ${ }^{*}$ significance at $\mathrm{p}<0.01$ and $\mathrm{p}<0.05$ probability levels; ns - not significantly different 
Table 2. The Eigen values for main traits in white lupine cultivars

\begin{tabular}{|c|c|c|c|c|}
\hline \multirow{3}{*}{ Trait } & \multicolumn{4}{|c|}{ Parameters } \\
\hline & \multicolumn{3}{|c|}{ Influence of factor } & \multirow{2}{*}{ Estimated variable communality } \\
\hline & F1 & F2 & F3 & \\
\hline Plant height & 0.879 & -0.179 & -0.212 & 0.850 \\
\hline Pods per plant & 0.922 & -0.276 & 0.149 & 0.948 \\
\hline Pod width & 0.939 & -0.221 & 0.151 & 0.954 \\
\hline Pod length & 0.968 & -0.079 & -0.086 & 0.950 \\
\hline Seeds per pod & 0.040 & 0.621 & -0.686 & 0.858 \\
\hline Seeds per plant & 0.554 & 0.514 & -0.376 & 0.712 \\
\hline Seed weight per plant & 0.107 & 0.715 & 0.136 & 0.542 \\
\hline Mass of 1,000 seeds & 0.407 & 0.636 & 0.513 & 0.833 \\
\hline Crude protein of seeds & -0.450 & -0.629 & -0.293 & 0.684 \\
\hline Crude fiber of seeds & 0.858 & -0.271 & -0.151 & 0.832 \\
\hline Eigen value & 4.865 & 2.198 & 1.099 & \\
\hline Variability (\%) & 48.653 & 21.982 & 10.994 & \\
\hline Cumulative \% & 48.653 & 70.634 & 81.629 & \\
\hline
\end{tabular}

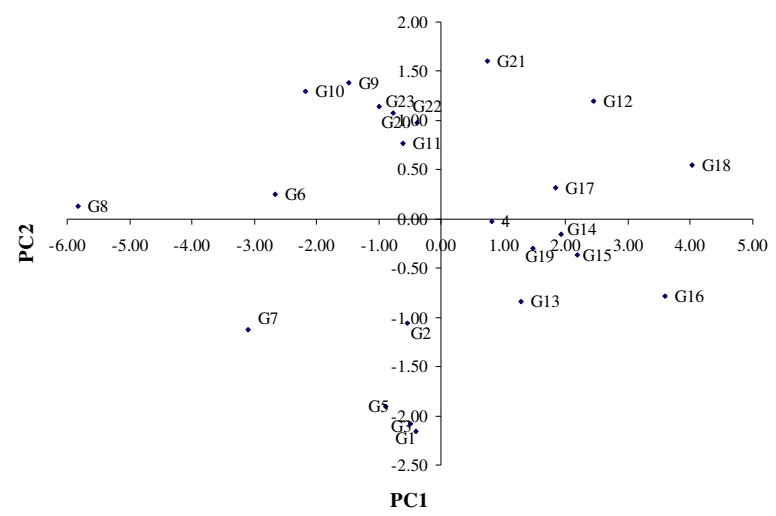

Fig. 1. Principal component analysis of white lupine cultivars regarding the studied traits. 1-'Astra', 2-'Nahrquell', 3-'Ascar', 4-'BGR 6305', 5-'Shienfield Gard', 6-'WAT', 7-'Kijewskij Mutant', 8-'Hetman', 9-'Start', 10-'Amiga', 11-'Garant', 12'Tel Keram', 13-'Bezimenii 1', 14-'Bezimenii 2', 15-'Pflugs Ultra', 16-'Termis Mestnii', 17-'Horizont', 18-'Solnechnii', 19'Pink Mutant', 20-'Manovitskii', 21-'Barde', 22-'Dega', 23'Desnyanskii'

'Tel Keram', 'Horizont', 'Solnechnii' and 'Barde' were separated from the group of the rest of white lupine cultivars studied. They had positive values for PC1 and PC2, as they were distinguished by higher values of plant height, number of seeds and pods per plant, seed weight, mass of 1,000 seeds and crude protein content. With negative values for PC2 and PC1 were 'Astra', 'Nahrquell', 'Ascar', 'Shienfield Gard' and 'Kijewskij Mutant'. They were characterized by a relatively smaller number of seeds and pods per plant, a low content of crude protein and high in crude fiber. PC1 had influence on the manifestation of traits plant height, number of seeds and pods per plant (Fig. 2) in cultivars 'Tel Keram', 'Bezimenii 1', 'Bezimenii 2', 'Pflugs Ultra', 'Termis Mestnii', 'Horizont', 'Solnechnii', 'Pink Mutant', while cultivars 'Start', 'Amiga', 'Manovitskii', 'Barde', 'Dega', 'Desnyanskii' were influenced by PC2, by the traits mass per 1000 seeds, number of seeds in a pod and seed weight per plant.

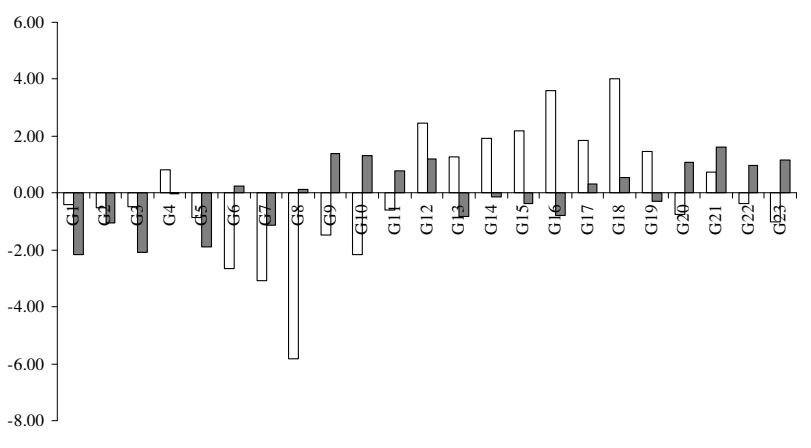

$\square \mathrm{PC} 1 \square \mathrm{PC} 2$

Fig. 2. Influence of PC1 and PC2 in white lupine cultivars. 1'Astra', 2-'Nahrquell', 3-'Ascar', 4-'BGR 6305', 5-'Shienfield Gard', 6-'WAT', 7-'Kijewskij Mutant', 8-'Hetman', 9-'Start', 10-'Amiga', 11-'Garant', 12-'Tel Keram', 13-'Bezimenii 1', 14'Bezimenii 2', 15-'Pflugs Ultra', 16-'Termis Mestnii', 17'Horizont', 18-'Solnechnii', 19-'Pink Mutant', 20'Manovitskii', 21-'Barde', 22-'Dega', 23-'Desnyanskii'

\section{Hierarchical cluster analysis}

Based on the results of the productivity components, a grouping of genetically related varieties was done. Table 3 showed the classification of the cultivars in two main clusters. The first cluster included 'Hetman', which was characterized by very low values for all quantitative traits, an average level of protein content and the highest crude fiber content in the tested group of cultivars.

The second cluster was subdivided into two major groups, such as 'Tel Keram' that occupied a self-place in the one group, and 'Desnyanskii', 'Dega Garant', 'Barde' whose traits had values close to the averages for the population and high content of crude protein. In the same subgroup, 'Start', 'Manovitskii', 'WAT', 'Amiga' and 'Kijewskij Mutant' were included, but genetically within each other, they were closer in regard to the traits plant height, mass of 1,000 seeds, number of pods and seed weight per plant. In the second 
Table 3. Cluster analysis of 23 studied white lupine cultivars

\begin{tabular}{|c|c|c|c|c|c|c|c|c|c|c|c|c|c|c|c|c|c|c|c|c|c|c|}
\hline № & 1 & 2 & 3 & 4 & 5 & 6 & 7 & 8 & 9 & 10 & 11 & 12 & 13 & 14 & 15 & 16 & 17 & 18 & 19 & 20 & 21 & 22 \\
\hline 2 & 1174 & & & & & & & & & & & & & & & & & & & & & \\
\hline 3 & 44 & 1085 & & & & & & & & & & & & & & & & & & & & \\
\hline 4 & 400 & 415 & 407 & & & & & & & & & & & & & & & & & & & \\
\hline 5 & 1946 & 157 & 1891 & 817 & & & & & & & & & & & & & & & & & & \\
\hline 6 & 8022 & 3834 & 8089 & 5472 & 3051 & & & & & & & & & & & & & & & & & \\
\hline 7 & 4932 & 1800 & 4956 & 3131 & 1388 & 459 & & & & & & & & & & & & & & & & \\
\hline 8 & 19636 & 12299 & 19630 & 15612 & 10735 & 2672 & 4905 & & & & & & & & & & & & & & & \\
\hline 9 & 6521 & 3090 & 6643 & 4217 & 2491 & 165 & 382 & 3962 & & & & & & & & & & & & & & \\
\hline 10 & 6744 & 2971 & 6778 & 4472 & 2419 & 119 & 209 & 3466 & 156 & & & & & & & & & & & & & \\
\hline 11 & 1312 & 765 & 1392 & 638 & 1123 & 3273 & 1615 & 11590 & 2235 & 2452 & & & & & & & & & & & & \\
\hline 12 & 5712 & 3098 & 6005 & 3396 & 2192 & 2554 & 2418 & 8881 & 1874 & 2650 & 3060 & & & & & & & & & & & \\
\hline 13 & 529 & 586 & 646 & 243 & 873 & 6072 & 3568 & 16480 & 4838 & 5066 & 1152 & 3328 & & & & & & & & & & \\
\hline 14 & 1091 & 657 & 1243 & 421 & 706 & 5259 & 3143 & 15064 & 4110 & 4437 & 1239 & 2275 & 120 & & & & & & & & & \\
\hline 15 & 333 & 1400 & 512 & 513 & 1971 & 8160 & 5234 & 19961 & 6567 & 6967 & 1640 & 4647 & 237 & 544 & & & & & & & & \\
\hline 16 & 1142 & 3610 & 1391 & 1812 & 4400 & 12570 & 9068 & 26718 & 10421 & 11219 & 3748 & 6963 & 1469 & 1912 & 624 & & & & & & & \\
\hline 17 & 535 & 664 & 682 & 256 & 1012 & 5940 & 3492 & 16307 & 4654 & 4903 & 973 & 3334 & 37 & 161 & 208 & 1484 & & & & & & \\
\hline 18 & 1352 & 2286 & 1655 & 1033 & 2526 & 8138 & 5776 & 19920 & 6380 & 7272 & 2228 & 3219 & 761 & 679 & 540 & 749 & 742 & & & & & \\
\hline 19 & 1758 & 1097 & 2007 & 749 & 972 & 3877 & 2407 & 12803 & 2730 & 3359 & 906 & 1201 & 713 & 385 & 1227 & 2725 & 679 & 796 & & & & \\
\hline 20 & 5950 & 2613 & 6108 & 3712 & 1956 & 301 & 352 & 4533 & 102 & 271 & 2084 & 1296 & 4054 & 3290 & 5728 & 9391 & 3912 & 5480 & 2137 & & & \\
\hline 21 & 7967 & 4285 & 8266 & 5221 & 3230 & 976 & 1582 & 4951 & 719 & 1290 & 3674 & 670 & 5398 & 4219 & 7174 & 10621 & 5275 & 5967 & 2617 & 482 & & \\
\hline 22 & 2642 & 1331 & 2869 & 1508 & 1328 & 1938 & 916 & 8922 & 1113 & 1414 & 363 & 1956 & 1813 & 1577 & 2601 & 5200 & 1580 & 2797 & 835 & 941 & 2008 & \\
\hline 23 & 4535 & 2204 & 4751 & 2840 & 1905 & 801 & 454 & 6100 & 298 & 559 & 1129 & 1764 & 3287 & 2800 & 4520 & 7790 & 3045 & 4508 & 1644 & 285 & 1097 & 295 \\
\hline
\end{tabular}

main subgroup of the second cluster, each of the cultivars 'Termis Mestnii' and 'Solnechnii' occupied a self-place. However, they were very close to each other in terms of their high productivity and productivity elements (plant height, number of seeds and pods per plant, mass of 1,000 seeds, and high crude protein content). The other subgroup consisted of the remaining cultivars: 'Pink 'Mutant', 'Nahrquell' and 'Shienfield Gard' that were genetically more distant than 'Bezimenii 1', 'Horizont', 'Bezimenii 2', 'Pflugs Ultra', 'BGR 6305', 'Astra' and 'Ascar', whose plants were high, did not form many pods, but they had more seeds with a weight over the average for the population.

Estimation of genetic parameters: genotypic (GCV\%) and phenotypic (PCV\%) coefficient of variation

Genetic and phenotypic parameters of investigated traits were presented in Table 4. Variability coefficients (GCV and PCV), taken as a whole, were lower for the traits of seed weight per plant, mass of 1,000 seeds, CP, CF and higher for seeds per pod. A relatively small difference was found between GCV (\%) and PCV (\%) in terms of seeds per plant, seed weight per plant and mass of 1,000 seeds, indicating that the influence of environment on the manifestation of these traits was small and the variation was due to genetic factors to a greater extent.

The magnitude of the phenotypic coefficient for plant height, pods per plant, pod length and seeds in a pod, was higher than the genotypic coefficient, which provided a good opportunity to improve these traits through phenotypic selection. For the qualitative indicators (crude protein and crude fiber content), the values of GCV (\%) were higher than those of PCV (\%), suggesting that the selection performed on these traits can be effective and improve new cultivars.

The value of the genetic variance for plant height, pods per plant, pod length, seeds per pod and seeds per plant, was less than their corresponding phenotypic variance, but higher for the qualitative indicators (CP and $\mathrm{CF}$ ). The genotypic deviations ranged from 0.01 to 814.62 . The genotypic variance was the highest for seeds number per plant, followed by pod length and plant height indicating a greater degree of genetic diversity for these traits. The phenotypic dispersion values ranged from 0.03 to 2326.77 . The slightest variation was for the mass of 1,000 seeds, seed weight per plant, CP and CF, while the traits of seeds per plant, pod length, plant height and pods per plant had a high variability, showing that these traits were the most strongly influenced by the environmental impact.

\section{Genetic advance and heritability (broad sense)}

Inheritance varied from $20.46 \%$ to $99.85 \%$, while genetic advance ranged from 0.12 (for mass per 1,000 seeds) to 34.79 (for seed weight per plant). In the present study, high inheritance in combination with high genetic advance was reported only for the number of seeds per plant. This indicated the additive nature of inheritance of these traits in the collection of white lupine cultivars. A high inheritance and low genetic advance characterized all the other traits, indicating the action of non-additive gene complexes in their manifestation.

\section{Correlation and path analysis}

The traits of pod length, seeds per pod and seeds per plant had a significant positive genotypic correlation with the seed weight per plant (Table 5), which meant that plant productivity increased with an increase in the meanings of these indicators. Plant productivity was in positive, although statistically non-significant, genotypic dependence also with the other parameters.

In the tested cultivars, a significant correlation with the crude protein content (CP) showed the pod length ( $\mathrm{r}=$ $0.534)$, seeds in a pod $(\mathrm{r}=0.416)$ and mass of 1,000 seeds $(\mathrm{r}$ $=0.714)$. Obviously, the protein content of seeds raised with increasing values for these traits.

A certain analogy was found in the dependences between seed weight per plant and pod length, seeds in a pod and seeds per plant, regarding the genotypic and phenotypic correlation. There was a significant positive phenotypic correlation between these traits and plant productivity.

The protein content correlated to the greatest extent with pod length $(r=0.490)$, seeds in a pod $(r=0.400)$ and 
Table 4. Distinctive features and genetic parameters of the investigated cultivars

\begin{tabular}{cccccccccccc}
\hline Trait & $\begin{array}{c}\text { Plant } \\
\text { height }\end{array}$ & $\begin{array}{c}\text { Pods per } \\
\text { plant }\end{array}$ & $\begin{array}{c}\text { Pod } \\
\text { width }\end{array}$ & $\begin{array}{c}\text { Pod } \\
\text { length }\end{array}$ & $\begin{array}{c}\text { Seeds per } \\
\text { pod }\end{array}$ & $\begin{array}{c}\text { Seeds per } \\
\text { plant }\end{array}$ & $\begin{array}{c}\text { Seed weight } \\
\text { per plant }\end{array}$ & $\begin{array}{c}\text { Mass of } \\
1,000 \\
\text { seeds }\end{array}$ & $\begin{array}{c}\text { Crude } \\
\text { protein }\end{array}$ & $\begin{array}{c}\text { Crude } \\
\text { fibre }\end{array}$ \\
\hline Minim & 24.67 & 14.97 & 2.75 & 5.13 & 1.04 & 153.85 & 5.37 & 0.96 & 24.8 & 10.73 \\
\hline Maxim & 125.08 & 57.17 & 27.00 & 113.75 & 31.32 & 374.81 & 8.64 & 1.99 & 33.32 & 19.66 \\
GCV $(\%)$ & 9.53 & 13.35 & - & 15.93 & 25.49 & 10.79 & 6.37 & 9.65 & 8.30 & 14.59 \\
\hline $\mathrm{GCV} /$ PCV $(\%)$ & 0.29 & 0.58 & - & 0.39 & 0.75 & 0.73 & 1.04 & 0.81 & 15.09 & 8.49 \\
$\sigma^{2} \mathrm{~g}$ & 35.23 & 17.83 & - & 61.01 & 10.18 & 814.62 & 0.21 & 0.01 & 6.07 & 3.66 \\
\hline$\sigma^{2} \mathrm{p}$ & 446 & 71.28 & 25.25 & 466.58 & 28.26 & 2.326 .77 & 0.41 & 0.03 & 6.09 & 3.71 \\
$\mathrm{H}^{2}(\%)$ & 20.46 & 50.02 & - & 31.10 & 62.81 & 61.78 & 76.45 & 66.38 & 99.85 & 99.54 \\
\hline $\mathrm{GA}$ & 3.44 & 4.35 & - & 5.82 & 3.94 & 34.79 & 0.68 & 0.12 & 5.07 & 3.91 \\
\hline $\mathrm{GG}(\%)$ & 58.10 & 48.22 & 69.55 & 74.86 & 67.68 & 37.59 & 18.83 & 24.19 & 17.49 & 26.12 \\
\hline
\end{tabular}

GCV - genotypic coefficient of variation; PCV - phenotypic coefficient of variation; $\sigma^{2} \mathrm{~g}$ - genotypic variances; $\sigma^{2} \mathrm{e}$ - environmental variance; GA - genetic advance; GG genetic gain; $\mathrm{H}^{2}$ - broad sense heritability $(\%)$

Table 5. Genotypic (above the diagonal) and phenotypic (under the diagonal) correlation coefficients ( $\mathrm{r}$ ) for the studied traits in white lupine cultivars

\begin{tabular}{ccccccccccc}
\hline & 1 & 2 & 3 & 4 & 5 & 6 & 7 & 8 & 9 \\
\hline 1 & & 0.979 & 0.437 & 0.500 & 0.671 & 0.772 & 0.636 & 0.381 & 0.104 \\
2 & 0.917 & & 0.475 & 0.573 & 0.732 & 0.823 & 0.728 & 0.419 & 0.272 \\
3 & 0.384 & 0.399 & & 0.956 & 0.861 & 0.612 & 0.459 & 0.367 & 0.474 \\
4 & 0.436 & 0.484 & 0.955 & & 0.912 & 0.639 & $0.610^{* * *}$ & 0.594 & $0.534^{*}$ \\
5 & 0.636 & 0.669 & 0.847 & 0.890 & & 0.890 & $0.806^{* * *}$ & 0.383 & $0.416^{*}$ \\
6 & 0.676 & 0.715 & 0.423 & 0.432 & 0.758 & & $0.838^{* * *}$ & 0.168 & 0.219 \\
7 & 0.542 & 0.631 & 0.433 & $0.558^{* * *}$ & $0.744^{* * *}$ & $0.679^{* * *}$ & & 0.435 & 0.458 \\
8 & 0.321 & 0.368 & 0.263 & 0.409 & 0.310 & 0.138 & 0.404 & & $0.714^{* * *}$ \\
9 & 0.097 & 0.250 & 0.433 & $0.490^{*}$ & $0.400^{*}$ & 0.199 & 0.417 & $0.602^{* * *}$ & $-0.643^{* * *}$ \\
10 & $-0.225^{* * *}$ & $-0.326^{*}$ & $-0.558^{* * *}$ & -0.564 & -0.497 & -0.452 & -0.449 & -0.439 & -0.45
\end{tabular}

1 - Plant height, 2 - Pods per plant, 3 - Pod width, 4 - Pod length, 5 - Seeds per pod, 6 - Seeds per plant, 7 - Seed weight per plant, 8 - Mass of 1,000 seeds, 9 - Crude protein, 10 - Crude fiber

***, ${ }^{* *}$ and ${ }^{*}$ significance at $\mathrm{p}<0.001, \mathrm{p}<0.01$ and $\mathrm{p}<0.05$ probability levels

Table 6. Path-coefficient analysis of seed productivity in white lupine cultivars

\begin{tabular}{|c|c|c|c|c|c|c|c|c|c|c|}
\hline \multirow[b]{2}{*}{ Direct effect } & \multicolumn{9}{|c|}{ Indirect effect } & \multirow{2}{*}{$\begin{array}{l}\text { Total } \\
\text { effect }\end{array}$} \\
\hline & Plant height & $\begin{array}{l}\text { Height to } \\
\text { the } 1 \text { pod }\end{array}$ & Pods per plant & $\begin{array}{c}\text { Seeds per } \\
\text { plant }\end{array}$ & $\begin{array}{c}\text { Mass of } \\
1,000 \text { seeds }\end{array}$ & $\begin{array}{l}\text { Pod } \\
\text { length }\end{array}$ & $\begin{array}{c}\text { Pod } \\
\text { width }\end{array}$ & $\begin{array}{l}\text { Crude } \\
\text { protein }\end{array}$ & $\begin{array}{l}\text { Crude } \\
\text { fibre }\end{array}$ & \\
\hline Plant height & 1.263 & 340.242 & 156.199 & -229.828 & -119.760 & 742.164 & -54.823 & -327.318 & -534.845 & 48.580 \\
\hline $\begin{array}{l}\text { Height to the } 1 \\
\text { pod }\end{array}$ & 59.825 & 12.691 & 149.238 & -287.668 & -145.536 & 772.350 & -52.865 & -324.699 & -555.475 & 28.630 \\
\hline Pods per plant & 122.832 & 607.258 & 20.472 & -792.237 & -116.450 & 713.018 & -50.418 & -326.009 & -545.160 & 7.940 \\
\hline Seeds per plant & 96.594 & 336.308 & 194.481 & -9.576 & -110.228 & 673.464 & -63.145 & -377.332 & -488.619 & 28.060 \\
\hline $\begin{array}{l}\text { Mass of 1,000 } \\
\text { seeds }\end{array}$ & 130.219 & 645.711 & 348.018 & -518.358 & -0.413 & 713.018 & -56.781 & -371.113 & -479.450 & 304.350 \\
\hline Pod length & 91.859 & 291.509 & 235.424 & -231.073 & -151.159 & 104.090 & -60.208 & -339.232 & -565.407 & 6.590 \\
\hline Pod width & 56.820 & 319.429 & 139.821 & -242.565 & -115.736 & 804.618 & -48.949 & -340.280 & -552.036 & 1.040 \\
\hline Crude protein & 123.274 & 555.225 & 409.433 & -730.183 & -115.066 & 738.000 & -54.334 & -13.093 & -558.722 & 27.870 \\
\hline Crude fibre & 96.910 & 293.159 & 238.085 & -372.322 & -112.839 & 755.695 & -60.697 & -403.517 & -38.203 & 12.310 \\
\hline
\end{tabular}

mass of 1,000 seeds $(r=0.602)$. A negative dependence was observed between crude fiber content and some other traits (plant height, pods per plant, protein content), but the correlation coefficients were not statistically significant.

Regarding seed productivity in white lupine cultivars (Table 6), the greatest direct effect had the traits of pod length (104.090) and pods per plant (20.472), followed by height to the first pod (12.691). Indirect effect on this trait had the pod length by means of increasing pod sizes (length and width), a higher location of the first pod and a greater plant height. The strongest indirect negative influence had the crude protein content and the increased number of pods per plant.

The values of total effect indicated that productivity raised to the greatest extent by increasing the mass of 1,000 seeds (304.350), plant height $(48,580)$ and number of seeds per plant. The length and width of the pods had the least effect on the seed weight of plants. 
402

Based on the established effects and dependencies between the studied traits in white lupine cultivars, it is possible to successfully predict the efficiency of hybridization carried out and then to be conducted an effective selection in this crop.

\section{Discussion}

In the present study, a high inheritance of all the traits and indicators was found with the exception of plant height where the inheritance coefficient was more moderate. The level of inheritance indicated that the environmental impact of the trait was minimal. Each of them could be used with success in breeding programs. According to Eid (2009), without preliminary information about the level of genetic advance, values of inheritance coefficient would not have a practical meaning in the breeding based on the phenotypic manifestation of the trait, so that both traits should be taken into account in analyzing a certain trait.

Dikshit et al. (2014) reported an average level of variation of the characteristics plant height, 1,000 seed weight, number of primary branches and number of seeds per pod in Lathyrus sativus cultivars. The values obtained in their studies about the correlation coefficient indicated that the pod length demonstrated positive and significant correlation with seeds per pod and days to maturity, highly and significantly correlated with seed weight. Aliu et al. (2016) reported a medium level of variation for the parameters of seed yield and mass of 1,000 seeds, and a strong variation for the biological yield and aboveground biomass in chickpeas. The hereby results did not completely correspond to those reported by the cited authors. The probable reason was the different culture that is the subject of the current study, as well as the impact of the changing environment.

High positive and significant dependencies were found between the yield and biological yield and yield and harvest index in lentil (Karadavut, 2009). According to El-Harty et al. (2016) and Annicchiarico et al. (2010) genotypes that were superior in one of the yield components can be involved in breeding programs for new varieties development.

The statistical methods and genetic parameters used for estimation of the collection of white lupine cultivars demonstrated that there was significant genetic diversity in regard to the studied traits. The grouping of cultivars in the present investigation will facilitate their future use in combinative breeding. Varieties of the groups with the best agronomic indicators are suitable for inclusion in hybridization schemes.

\section{Conclusions}

The diversity of groups regarding the different traits and indicators showed the presence of genetic diversity within the studied 23 white lupine cultivars, which was a good prerequisite for starting a breeding program in this crop. The most favorable combination of a high seed productivity and crude protein content had cultivars 'Tel Keram', 'Pflugs Ultra', 'WAT', 'Solnechnii' and 'Pink Mutant' whose plants also characterized with a mass of 1,000 seeds between 15 and $21 \mathrm{~g}$. Genetically, the most distant from each other were
'Bezimenii 1' and 'Pflugs Ultra' compared to 'Termis Mestnii' and 'Solnechnii' and to 'Tel Keram'. These cultivars are suitable as genitors for the development of high-yielding white lupine cultivars. The traits of pod length, number of seeds in a pod and seeds per plant showed a high positive phenotypic and genotypic correlation with the seed productivity in white lupine. In the breeding on productivity, it can be rely upon the mass of 1,000 seeds, plant height and number of seeds per plant, due to their highest total effect on the seed weight per plant.

\section{Acknowledgements}

The authors thank the Agricultural Academy in Bulgaria for funding the study.

\section{References}

Ajmal SU,Zakir N, Mujahid MY (2009). Estimation of genetic parameters and character association in wheat. Research Journal of Agriculture and biological Sciences 1:15-18.

Aliu S, Kaul HP, Rusinovci I, Shala-Mayrhofer V, Fetahu S, Zeka D (2016). Genetic diversity for some nutritive traits of chickpea (Cicer arietinum L) from different regions in Kosova. Turkish Journal of Field Crops 21(1):156-161.

Annicchiarico P, Harzic N, Carroni AM (2010). Adaptation, diversity, and exploitation of global white lupin (Lupinus albus L.) landrace genetic resources. Field Crops Research 119:114124.

Ayan I, Mut H, Basaran U, Acar Z, Asci O (2012). Forage potential of cowpea (Vigna ungriculata L. Walp). Turkish Journal of Field Crops 17(2):135-138.

Bozokalfa MK, Esiyok D, Ilbi H, Kaygisiz Asciogul T (2010). Estimates of genetic variability and association studies in quantitative plant traits of Erucaspp.landraces. Genetika 42(3):501-512.

Burton GW (1952). Quantitative inheritance in grasses. Proc. 6th Int. Grassld. Cong. 1 pp 277-283.

Caliskan S, Erdogan C, Arslan M, Caliskan ME (2013). Comparison of organic and traditional production systems in chickpea (Cicer arietinium L.). Turkish Journal Field Crops 18:3439.

Cowen NM, Frey KY (1987). Relationship between genealogical distance and breedingbehavior in oats. Euphytica 36:413-424.

Cruz CD (2009). Programa genes: Biometria. version 7.0. University of Federal Viçosa, Viçosa, Brazil.

Dikshit N, Nizar MA, Sivaraj N (2014). Phenotypic variability in grass pea (Lathyrus sativus L.) germplasm of Vidarbha region of Maharashtra, India. Legume Research-An International Journal 37(5):556-558.

Eid MH (2009). Estimation of heritability and genetic advance of yield traits in wheat (Triticum aestivum $\mathrm{L}$.) under drought condition. International Journal of Genetics and Molecular Biology 1(7):115-120.

El-Harty E, Ashrie A, Ammar M, Alghamdi S (2016). Genetic variation among egyptian white lupin (Lupinus albus L.) genotypes. Turkish Journal Field Crops 21(1):148-155.

El-Sherif NA, Mohamed AA, Saad ME, Barakat H, Aly S (2014). Genetic variation in egyptian white lupin (Lupinus albus $\mathrm{L}$ ) genotypes based on combined data of ISSR and fluorescence-based AFLP markers. 
403

Egyptian Journal of Genetics and Cytology 43(1):1-23.

Esiyok D, MK Bozokalfa, Asciogul TK (2011). Variability, heritability and association analysis in plant traits of swiss chard (Beta vulgaris subsp. cicla). Genetika 43(2):239-252.

Jansen PCM (2006). Lupinus albus (L.) record from protabase. In: Brink M, Belay G (Eds). PROTA - Plant Resources of Tropical Africa. Wageningen, Netherlands.

Johnson HW, Robinson HF, Comstock RE (1995). Estimates of genetic and environmental variability in soya beans. Agronomy Journal 47:314 318.
Karadavut U (2009). Path analysis for yield and yield components in lentil (Lensculinaris Medik).). Turkish Journal of Field Crops 14(2):97-104.

Khaidizar MI, Haliloglu K, Elkoca E, Aydin M, Kantar F (2012). Genetic diversity of common bean (Phaseolus vulgaris L.) landraces grown in northeast Anatolia of Turkey assessed with simple sequence repeat markers. Turkish Journal of Field Crops 17(2):145-150.

Kurlovich BS (2002). Lupins: geography, classification, genetic resources and breeding. St. Petersburg, Publiching House Intan.

Mahmud I, Kramer HH (1951). Segregation for yield high and maturity fallowing a soybean cross. Agricultural Journal 1:505-509. 